\title{
Invasion impact by Pteridium arachnoideum (Kaulf.) Maxon (Dennstaedtiaceae) on a neotropical savanna
}

\author{
Natalia Guerin ${ }^{1 \star}$ and Giselda Durigan ${ }^{2}$
}

Received: August 18, 2014 Accepted: January 14, 2015

\begin{abstract}
Whether management intervention is required to control biological invasions depends primarily on demonstrating species losses resulting from such invasions. Brackens of the Pteridium genus are currently regarded as a problem species that act as important ecological filters in the assembly of invaded communities. We investigated the effects of Pteridium arachnoideum invasion on the diversity, structure, floristic composition, and functional traits of cerradão in Assis, São Paulo, Brazil. We compared an invaded site with an adjacent non-invaded site. Bracken constrained the establishment of tree species, resulting in a community structure remarkably distinct from the non-invaded area. The density and basal area of the arboreal community were higher in non-invaded areas, but large trees were more frequent in the invaded areas. However, bracken did not reduce tree species diversity. Both richness and diversity were higher in the invaded area, indicating that over time, tree species richness and diversity naturally recovered, albeit slowly, in the invaded area. Therefore, one cannot attribute the loss of richness in the Cerrado vegetation to bracken invasion. Hence, we argue that, in this system, eradication of this invasive species is not likely to be cost effective, and thus, it should be a low management priority.
\end{abstract}

Keywords: assembly rules, bracken, Brazil, cerradão, ecological filters, ecosystem management

\section{Introduction}

Biological invasion occurs when a species acquires a competitive advantage, and combined with a lack of natural barriers to prevent its proliferation, it can spread quickly into new areas and dominate recipient ecosystems (Valéry et al. 2008). The impact of biological invasions has been the subject of considerable discussion in the literature (Cronk \& Fuller 1995; McGeoch et al. 2010; Simberloff \& Rejmánek 2011; Williamson 1996). Biological invasions modify ecosystem processes (Raizada et al. 2008) and decrease species richness and abundance through several mechanisms, such as predation, competition, and hybridization, and alter community structure and genetic diversity (McKinney \& Lockwood 1999). Once biological invaders are well established in recipient ecosystems, reversal of the invasion process is rarely cost effective. Therefore, the long-term impacts of invaders on species diversity need to be carefully evaluated before considerable effort is made to control the invader and to restore an ecosystem (Norton 2009).

Although bracken ferns of the Pteridium genus were already part of plant communities prior to human settlement and agriculture, they are currently regarded as a problem species in various regions of Brazil (Matos \& Pivello 2009; Portela et al. 2009) and other parts of the world (Marrs et al. 1997; Marrs \& Watt 2006). Characterized by large fronds and rapidly expanding rhizomes, brackens reduce the establishment of native vegetation (Marrs \& Watt 2006), and act as an important ecological filter in the assembly of invaded communities (Matos \& Belinato 2010). Species of Pteridium produce large quantities of dry biomass, increasing the frequency and intensity of wildfires (Ghorbani et al. 2006; Portela et al. 2009; Silva \& Matos 2006), and can also alter the soil seed bank and hinder the establishment of native species due to allelopatic compounds (Gliessman \& Müller 1978).

Invasions by bracken have been the subject of several recent studies in Brazil, which have shown the negative impacts of bracken species on native ecosystems (Matos \& Belinato 2010; Matos \& Pivello 2009; Portela et al. 2009; Salgado 2012), on economic activities (Furlan et al. 2014), and on human health (Hojo-Souza et al. 2010). However, one study demonstrated that bracken populations could diminish over time and possibly succumb to forest succession (Pinheiro \& Durigan 2009). The study monitored the changes in an area occupied by different Cerrado physiognomies

\footnotetext{
${ }_{1}^{1}$ Programa de Ecologia Aplicada, Escola Superior de Agricultura Luiz de Queiroz, Universidade de São Paulo, Avenida Pádua Dias, 11, 13418-900, Piracicaba, SP, Brazil (5511) 97204-6620

${ }^{2}$ Instituto Florestal, Floresta Estadual de Assis, PO Box 104, 19802-970, Assis, SP, Brazil

*Corresponding author: na.guerin@gmail.com
} 
over 44 years after fire suppression at Assis Ecological Station, and recorded a considerable decrease in the area occupied by bracken and a slow and sparse colonization by native trees. At the same time, the savanna vegetation in the non-invaded areas was replaced by cerradão, the forest type of Cerrado vegetation. The study indicated that changes in the invaded and non-invaded environments followed different pathways, and these observations motivated the present study.

We compared the plant community and succession processes of areas invaded by Pteridium arachnoideum with the areas not invaded by this species. Our hypothesis was that bracken hindered colonization by native species, resulting in reduced richness in the invaded community. To understand the interspecific differences in how native tree species respond to bracken invasion, we identified and quantified various functional traits of these species and measured the size-class structure of the community. Functional traitbased responses to bracken invasion enabled us to make recommendations for the management and restoration of ecosystems under similar conditions.

\section{Material and methods}

\section{Study area}

The Assis Ecological Station (EEcA) is located between $22^{\circ} 33^{\prime} 65^{\prime \prime} \mathrm{S}$ and $22^{\circ} 36^{\prime} 68^{\prime \prime} \mathrm{S}$ and between $50^{\circ} 23^{\prime} 00^{\prime \prime} \mathrm{W}$ and $50^{\circ} 22^{\prime} 29^{\prime \prime} \mathrm{W}$ in the municipality of Assis, São Paulo, Brazil, at 520-590 $\mathrm{m}$ above sea level. The land relief of the region consists of broad and flat hills with predominantly rectilinear slopes. Soils of the study area were identified as loamy Rhodic Hapludox and Quartzipsamments, all with high aluminum saturation (Bognola et al. 1996). According to Köppen's classification, the study area is located in the transition zone between the Cwa and the Cfa climate types, which are both humid subtropical climates. The average annual rainfall is about $1400 \mathrm{~mm}$, concentrated in the austral summer, and severe frosts sporadically occur (Brando \& Durigan 2004). The mean annual temperature is $22^{\circ} \mathrm{C}$, mean maximum is $28.7^{\circ} \mathrm{C}$, and mean minimum is $15.4^{\circ} \mathrm{C}$ (CEPAGRI 2014). The EEcA preserve includes 1312 ha of Cerrado vegetation and is one of the last remnants of Cerrado in the western part of São Paulo State. At present, the Cerrado in EEcA is composed of two distinct vegetation types: cerrado sensu stricto, a typical savanna physiognomy, in small patches, and cerradão, the forest type of Cerrado vegetation, in the majority of the area (Pinheiro \& Durigan 2012). However, these vegetation types have changed considerably in the last decades, after suppression of fires and other disturbances, and the area occupied by Pteridium arachnoideum (Kaulf.) Maxon has also changed (Pinheiro \& Durigan 2009). From 1962 to 1984, the area occupied by bracken increased from 71 to 93 ha (31\%). However, from 1994 to 2006, a rapid encroachment of the native vegetation was recorded, and the area occupied by bracken decreased from 91 to 39 ha, restricting its distribution to a little over half of the area it occupied in 1962. In this study, two adjacent sample sites were selected, one invaded by bracken and the other not. Both sites are located in the same watershed, at the same position in the slope. In 1962, the two sites were used as pastures, with no trees.

\section{The invasive species}

Pteridium is a widely distributed genus of fern, adapted to a broad range of environments because of physiological and ecological traits (Gliessman \& Muller 1978; Marrs \& Watt 2006). It occurs in all continents, except Antarctica. In Brazil, Pteridium arachnoideum occurs mostly above 800 $\mathrm{m}$ above sea level from Bahia to Rio Grande do Sul. The ideal habitat for the species corresponds to high altitudes, cold and rainy weather, and acidic and well drained soils (Tokarnia et al. 2000). This aggressive weed is very efficient at occupying pastures and disturbed forested areas because of a well-developed vascular system and a fire resistant underground rhizome structure (Roos et al. 2010) that is chemically resistant to herbivory and competitors (Fenwick 1989; Gliessman \& Muller 1978; Hojo-Souza et al. 2010; Marrs et al. 2000). The density and height of the fronds, which are spore-bearing leaves, increases when exposed to full light and high temperature (Roos et al. 2010), and they can reach up to $3 \mathrm{~m}$. The species can also survive in shaded environments, propagating by spores and by long-living rhizomes. However, it is susceptible to severe winters and frosts (Marrs \& Watt 2006).

\section{Sampling}

Preliminary studies by aerial photography and remote sensing (Pinheiro \& Durigan 2009) showed that the density of the vegetation was very different between invaded and non-invaded areas and, thus, distinct sampling methods were used to analyze the different attributes of the communities. For richness and diversity analyses of the overstory trees, we used the point-centered quarter method, with the aim of standardizing the number of individuals sampled in the two communities. For structural analyses (density and basal area) we used plots to avoid the biases from the point-centered quarter method, which depends on the spatial distribution of the individuals sampled (Gorenstein et al. 2007).

For the point-centered quarter method, we sampled 400 individuals with diameter at breast height $(\mathrm{DBH}) \geq 5 \mathrm{~cm}$, at 100 points distributed along 10 transects in each community. The distance between transects was $30 \mathrm{~m}$ in the invaded area and $25 \mathrm{~m}$ in the smaller non-invaded area. Because of the low density of trees in the area with P. arachnoideum, the distance between consecutive points on the transect was $20 \mathrm{~m}$, which prevented the same individual 
from being sampled twice. To standardize the sampling, the same distance was adopted for the area without $P$. arachnoideum. No measurements were made of individuals, nor of the distance from point to tree, as is typically done for the point-centered quarter method, because only presence of the species and their relative abundance in each community were analyzed. For a comparison of the functional traits between communities, species were classified according to their seed dispersal syndrome (animal dispersed or not, based on Pijl 1982), their growth rhythm (slow, moderate or fast), tolerance to frost (tolerant or susceptible), and shade affinity (tolerant or intolerant), following the classification proposed by Durigan et al. (2004). Species were identified in the field or by comparison with material from the Botany Collection of the Assis State Forest.

We used plots in three size classes (Muller-Dombois \& Ellenbergh 1974) to assess the structure of the tree community. Fifteen plots were distributed systematically at each site from a random point. We sampled the upper stratum $(\mathrm{DBH}$ $\geq 5 \mathrm{~cm}$ in $10 \mathrm{~m} \times 30 \mathrm{~m}$ plots $)$, intermediate stratum $(1 \mathrm{~cm} \leq$ $\mathrm{DBH}<5 \mathrm{~cm}$ in a subplot of $2 \mathrm{~m} \times 30 \mathrm{~m}$ ), and lower stratum (height $\geq 50 \mathrm{~cm}$ and $\mathrm{DBH}<1 \mathrm{~cm}$, in four subplots of $2 \mathrm{~m}$ $\times 2 \mathrm{~m}$ within each plot) (Fig. 1). We measured the height of all sampled woody individuals and DBH for intermediate and upper strata. For canopy cover estimation we used the line interception method (Canfield 1941), whereby we measured the projection of the upper stratum over two 30 $m$ longitudinal parallel lines within each plot. We counted all fronds of $P$. arachnoideum for the density calculation and visually estimated the percentage of ground cover by necromass of $P$. arachnoideum in the $2 \mathrm{~m} \times 2 \mathrm{~m}$ subplots.

\section{Data analysis}

Using the data obtained through the point-centered quarter method, we compared the diversity of the overstory trees between the two areas through the Shannon diversity index $\left(\mathrm{H}^{\prime}\right)$ and compared the richness by using rarefaction curves (Magurran 1988) with the software PAST (Hammer et al. 2001). The data obtained from the point-centered quarter method and from the plots and subplots were used to calculate the floristic similarity between strata within the communities and between communities using the Jaccard similarity index. We applied chi-square tests using the program R 2.10.0 (R Development Core Team 2009) to compare the frequency of functional traits between communities.

To compare the vegetation structure, we used mean values of the density (individuals ha ${ }^{-1}$ ), basal area $\left(\mathrm{m}^{2} \mathrm{ha}^{-1}\right)$, and canopy cover (\%). The effect of bracken on the understory was assessed by the Spearman correlation analysis using the density of the lower stratum, the ground cover of the P. arachnoideum necromass, and the density of the bracken fronds.

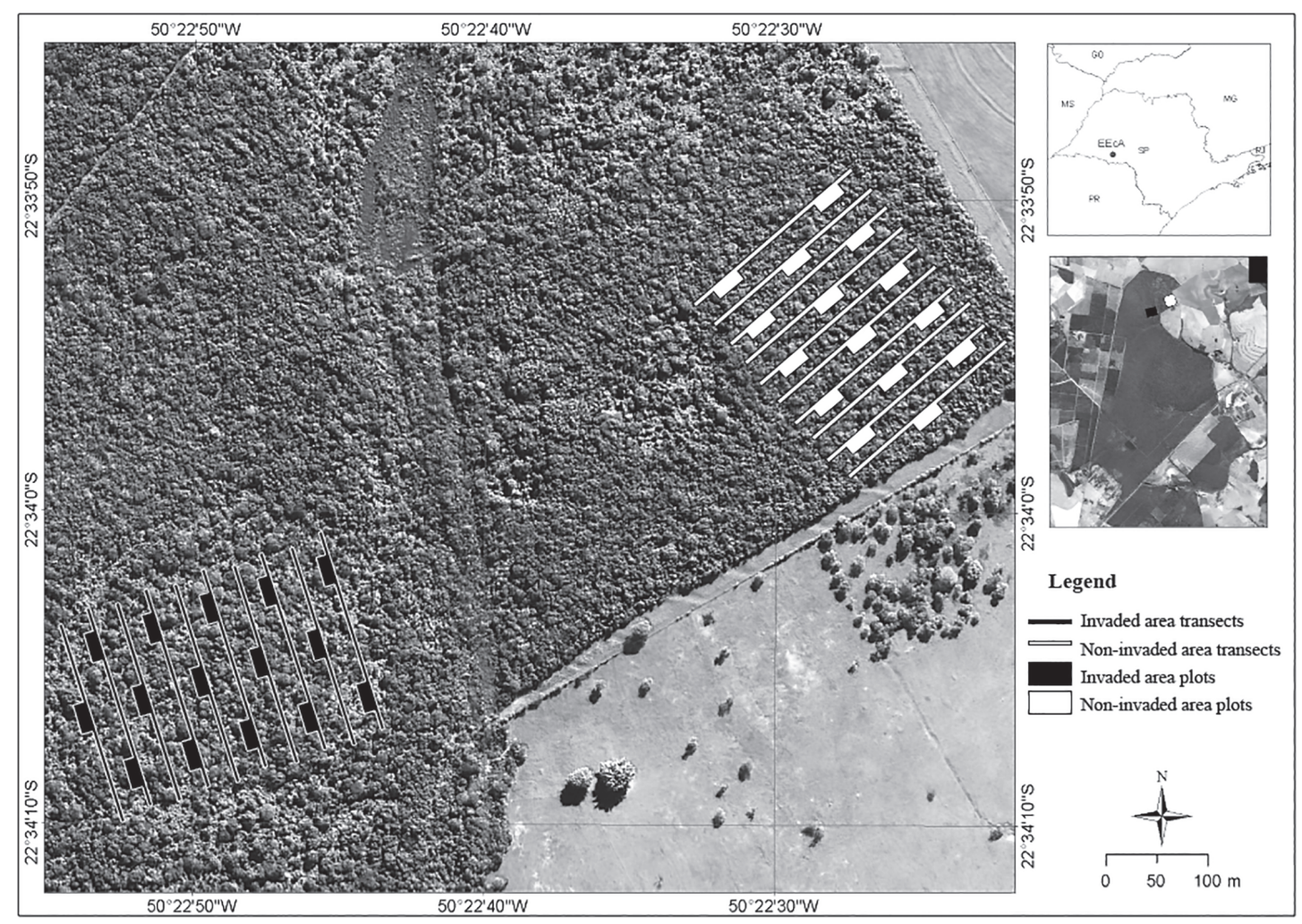

Figure 1: Location of transects used for sampling plots of cerradão invaded (in black) and non-invaded (in white) by Pteridium arachnoideum at Assis Ecological Station, SP, Brazil. (Figure by Eduardo da Silva Pinheiro, based on a Quickbird 2006 image). 


\section{Results}

Seventy-three native species were recorded in all strata in the two communities (Tab. 1). From this, 56 were sampled in the invaded area and 45 in the non-invaded area. Among the whole set of recorded woody species, 28 occurred only in the area with $P$. arachnoideum, 17 were unique to the non-invaded area, and 28 species were recorded in both communities (ISj $=38 \%$ ).

In the non-invaded community, the upper and lower strata were floristically similar ( $49 \%$ of species in common). In the invaded community, the similarity between the lower stratum and the upper or intermediate strata was low (13\% and $27 \%$, respectively). In both communities combined, the understory comprising the intermediate and lower strata shared $55 \%$ of all species. However, only $37 \%$ floristic similarity occurred in the upper stratum, which comprised the first species to colonize the study areas (Tab. 2).

Comparing the 400 trees sampled in each community through the point-centered quarter method, a greater relationship between tree species richness and abundance was found in the invaded community (Fig. 2). That resulted in a higher diversity of species occurred in the invaded area $\left(\mathrm{H}^{\prime}=3.2\right.$; $\left.\mathrm{CI}=3.217-3.45 ; 95 \%\right)$ than in the non-invaded area $\left(\mathrm{H}^{\prime}=2.951\right.$; $\left.\mathrm{CI}=3.211-3.446 ; 95 \%\right)$.

In general, the invaded community had a higher frequency of individuals that were dispersed by animals $\left(\chi^{2}=21.9387 ; d f=1 ; p<0.01\right.$; Fig. $\left.3 \mathrm{~A}\right)$; were shade toler-

Table 1. Species found in areas of cerradão invaded and non-invaded by Pteridium arachnoideum at the Assis Ecological Station, SP, Brazil. DS: seed dispersal syndrome (Z: zoochorous, NZ: non-zoochorous); GR: growth rhythm (F: fast, M: moderate, S: slow); ST: shade tolerance (T: tolerant, I: intolerant); SF: susceptibility to frost (T: tolerant to frost, S: susceptible to frost); DD: data deficient

\begin{tabular}{|c|c|c|c|c|c|c|}
\hline Family/Species & Non invaded area & Invaded area & DS & GR & ST & SF \\
\hline \multicolumn{7}{|l|}{ ANACARDIACEAE } \\
\hline Lithraea molleoides (Vell) Engl. & $\mathrm{X}$ & $\mathrm{X}$ & $\mathrm{Z}$ & $\mathrm{M}$ & $\mathrm{T}$ & $\mathrm{T}$ \\
\hline Tapirira guianensis Aubl. & $\mathrm{x}$ & $\mathrm{X}$ & $\mathrm{Z}$ & $\mathrm{M}$ & $\mathrm{T}$ & S \\
\hline \multicolumn{7}{|l|}{ ANNONACEAE } \\
\hline Xylopia aromatica (Lam.) Mart. & $\mathrm{x}$ & $\mathrm{X}$ & $\mathrm{Z}$ & S & $\mathrm{T}$ & S \\
\hline \multicolumn{7}{|l|}{ APOCYNACEAE } \\
\hline Tabernaemontana hystrix Steud. & $\mathrm{x}$ & & $\mathrm{Z}$ & $\mathrm{M}$ & $\mathrm{T}$ & $\mathrm{DD}$ \\
\hline \multicolumn{7}{|l|}{ ARECACEAE } \\
\hline Syagrus romanzoffiana (Cham.) Glassman & $\mathrm{x}$ & $\mathrm{x}$ & $\mathrm{Z}$ & S & $\mathrm{T}$ & $\mathrm{T}$ \\
\hline \multicolumn{7}{|l|}{ ASTERACEAE } \\
\hline Gochnatia polymorpha (Less.) Cabrera & $\mathrm{x}$ & $\mathrm{X}$ & $\mathrm{NZ}$ & $\mathrm{F}$ & I & $\mathrm{T}$ \\
\hline Piptocarpha axillaris (Less.) Baker & & $\mathrm{X}$ & $\mathrm{NZ}$ & $\mathrm{F}$ & I & $\mathrm{DD}$ \\
\hline \multicolumn{7}{|l|}{ BIGNONIACEAE } \\
\hline Handroanthus ochraceus (Cham.) Mattos & & $\mathrm{X}$ & $\mathrm{NZ}$ & S & I & $\mathrm{T}$ \\
\hline Zeyheria montana Mart. & & $\mathrm{x}$ & $\mathrm{NZ}$ & M & I & $\mathrm{T}$ \\
\hline \multicolumn{7}{|l|}{ BORAGINACEAE } \\
\hline Cordia ecalyculata Vell. & $\mathrm{X}$ & & $\mathrm{Z}$ & $\mathrm{M}$ & $\mathrm{T}$ & $\mathrm{DD}$ \\
\hline \multicolumn{7}{|l|}{ BURSERACEAE } \\
\hline Protium heptaphyllum (Aubl.) Marchand & & $\mathrm{x}$ & $\mathrm{Z}$ & $\mathrm{M}$ & $\mathrm{T}$ & $\mathrm{T}$ \\
\hline \multicolumn{7}{|l|}{ CELASTRACEAE } \\
\hline Maytenus gonoclada Mart. & & $\mathrm{x}$ & $\mathrm{Z}$ & $\mathrm{M}$ & $\mathrm{T}$ & $\mathrm{DD}$ \\
\hline \multicolumn{7}{|l|}{ CLETHRACEAE } \\
\hline Clethra scabra Pers. & & $\mathrm{x}$ & $\mathrm{NZ}$ & M & $\mathrm{T}$ & $\mathrm{T}$ \\
\hline \multicolumn{7}{|l|}{ COMBRETACEAE } \\
\hline Terminalia argentea Mart. & $\mathrm{x}$ & & $\mathrm{NZ}$ & S & I & S \\
\hline Terminalia glabrescens Mart. & $\mathrm{x}$ & $\mathrm{x}$ & $\mathrm{NZ}$ & M & I & S \\
\hline Terminalia triflora (Griseb.) Lillo & $\mathrm{x}$ & & $\mathrm{NZ}$ & S & I & $\mathrm{DD}$ \\
\hline \multicolumn{7}{|l|}{ ERYTHROXYLACEAE } \\
\hline Erythroxylum deciduum A. St.-Hil. & & $\mathrm{x}$ & $\mathrm{Z}$ & S & $\mathrm{T}$ & $\mathrm{T}$ \\
\hline
\end{tabular}


Table 1. Continuation.

\begin{tabular}{|c|c|c|c|c|c|c|}
\hline Family/Species & Non invaded area & Invaded area & DS & GR & ST & SF \\
\hline \multicolumn{7}{|l|}{ EUPHORBIACEAE } \\
\hline Alchornea triplinervia (Spreng.) Muell. Arg. & & $\mathrm{x}$ & $\mathrm{NZ}$ & $\mathrm{F}$ & $\mathrm{T}$ & $\mathrm{DD}$ \\
\hline Croton floribundus Spreng & $\mathrm{X}$ & $\mathrm{X}$ & $\mathrm{NZ}$ & $\mathrm{F}$ & I & S \\
\hline Sebastiania sp & & $\mathrm{X}$ & $\mathrm{NZ}$ & $\mathrm{DD}$ & $\mathrm{DD}$ & $\mathrm{DD}$ \\
\hline \multicolumn{7}{|l|}{ FABACEAE } \\
\hline Copaifera langsdorffii Desf. & $\mathrm{X}$ & $\mathrm{X}$ & $\mathrm{NZ}$ & M & $\mathrm{T}$ & $\mathrm{T}$ \\
\hline Inga vera subsp. affinis (DC.) T.D.Penn. & & $\mathrm{x}$ & $\mathrm{Z}$ & $\mathrm{F}$ & I & $\mathrm{T}$ \\
\hline Machaerium aculeatum Raddi & & $\mathrm{x}$ & $\mathrm{NZ}$ & M & I & $\mathrm{T}$ \\
\hline Machaerium acutifolium Vogel & $\mathrm{X}$ & $\mathrm{x}$ & $\mathrm{NZ}$ & $\mathrm{M}$ & $\mathrm{DD}$ & S \\
\hline Machaerium brasiliense Vogel & $\mathrm{X}$ & $\mathrm{x}$ & $\mathrm{NZ}$ & M & I & $\mathrm{T}$ \\
\hline Ormosia arborea (Vell.) Harms & & $\mathrm{x}$ & $\mathrm{NZ}$ & M & $\mathrm{T}$ & $\mathrm{DD}$ \\
\hline Peltophorum dubium (Spreng.) Taub. & $\mathrm{X}$ & & $\mathrm{NZ}$ & $\mathrm{F}$ & I & $\mathrm{T}$ \\
\hline Platypodium elegans Vogel & $\mathrm{X}$ & $\mathrm{x}$ & $\mathrm{NZ}$ & M & I & $\mathrm{T}$ \\
\hline Senegalia polyphylla (DC.) Britton \& Rose & $\mathrm{x}$ & & $\mathrm{NZ}$ & $\mathrm{F}$ & I & $\mathrm{T}$ \\
\hline Stryphnodendron rotundifolium Mart. & $\mathrm{x}$ & $\mathrm{x}$ & $\mathrm{NZ}$ & S & I & S \\
\hline \multicolumn{7}{|l|}{ LAURACEAE } \\
\hline Endlicheria paniculata (Spreng) J.F. Macbr & & $\mathrm{X}$ & $\mathrm{Z}$ & M & $\mathrm{T}$ & $\mathrm{DD}$ \\
\hline Nectandra cuspidata (Nees) & $\mathrm{X}$ & $\mathrm{X}$ & $\mathrm{Z}$ & $\mathrm{M}$ & $\mathrm{T}$ & $\mathrm{T}$ \\
\hline Nectandra oppositifolia Nees & & $\mathrm{x}$ & Z & M & $\mathrm{T}$ & $S$ \\
\hline Ocotea corymbosa (Meisn.) Mez & $\mathrm{x}$ & $\mathrm{X}$ & $\mathrm{Z}$ & M & $\mathrm{T}$ & S \\
\hline Ocotea velloziana (Meisn.) Mez & $\mathrm{X}$ & $\mathrm{x}$ & $\mathrm{Z}$ & M & $\mathrm{T}$ & $\mathrm{DD}$ \\
\hline Ocotea velutina (Nees) Rohwer & $\mathrm{X}$ & & $\mathrm{Z}$ & M & $\mathrm{T}$ & $\mathrm{DD}$ \\
\hline Ocotea venulosa (Nees) Baitelo & & $\mathrm{X}$ & Z & $\mathrm{DD}$ & $\mathrm{DD}$ & $\mathrm{DD}$ \\
\hline Persea willdenovii Kosterm. & $\mathrm{X}$ & $\mathrm{x}$ & $\mathrm{Z}$ & $\mathrm{DD}$ & $\mathrm{DD}$ & $\mathrm{DD}$ \\
\hline \multicolumn{7}{|l|}{ LOGANIACEAE } \\
\hline Strychnos brasiliensis Mart. & $\mathrm{X}$ & & $\mathrm{Z}$ & $\mathrm{M}$ & I & $\mathrm{DD}$ \\
\hline \multicolumn{7}{|l|}{ LYTHRACEAE } \\
\hline Lafoensia pacari A. St.-Hil. & & $\mathrm{x}$ & $\mathrm{NZ}$ & M & $\mathrm{T}$ & $\mathrm{DD}$ \\
\hline \multicolumn{7}{|l|}{ MALPIGHIACEAE } \\
\hline Byrsonima laxiflora Griseb. & $\mathrm{X}$ & $\mathrm{X}$ & $\mathrm{Z}$ & $\mathrm{DD}$ & $\mathrm{DD}$ & $\mathrm{DD}$ \\
\hline Byrsonima ligustrifolia A. Juss. & $\mathrm{X}$ & & $\mathrm{Z}$ & $\mathrm{DD}$ & $\mathrm{DD}$ & $\mathrm{DD}$ \\
\hline \multicolumn{7}{|l|}{ MALVACEAE } \\
\hline Luehea candicans Mart. \& Zucc. & $\mathrm{x}$ & & $\mathrm{NZ}$ & M & $\mathrm{T}$ & $\mathrm{T}$ \\
\hline Luehea grandiflora Mart. \& Zucc. & & $\mathrm{X}$ & $\mathrm{NZ}$ & M & $\mathrm{T}$ & $\mathrm{T}$ \\
\hline \multicolumn{7}{|l|}{ MELASTOMALACEAE } \\
\hline Miconia ligustroides (DC.) Naudin & & $\mathrm{x}$ & $\mathrm{Z}$ & M & $\mathrm{T}$ & S \\
\hline \multicolumn{7}{|l|}{ MELIACEAE } \\
\hline Cabralea canjerana (Vell.) Mart. & $\mathrm{x}$ & $\mathrm{x}$ & $\mathrm{Z}$ & M & $\mathrm{T}$ & $\mathrm{T}$ \\
\hline \multicolumn{7}{|l|}{ MYRTACEAE } \\
\hline Calyptranthes lucida Mart. ex DC. & & $\mathrm{x}$ & $\mathrm{Z}$ & S & $\mathrm{T}$ & $\mathrm{T}$ \\
\hline Eugenia florida DC. & $\mathrm{x}$ & & $\mathrm{Z}$ & $S$ & $\mathrm{~T}$ & \\
\hline Myrcia splendens (Sw.) DC. & & $\mathrm{X}$ & $\mathrm{Z}$ & S & $\mathrm{T}$ & $\mathrm{T}$ \\
\hline Myrcia guianensis (Aubl.) DC. & $\mathrm{X}$ & $\mathrm{x}$ & $\mathrm{Z}$ & $S$ & $\mathrm{~T}$ & \\
\hline Myrcia multiflora (Lam.) DC. & $\mathrm{X}$ & $\mathrm{X}$ & $\mathrm{Z}$ & S & $\mathrm{T}$ & $\mathrm{T}$ \\
\hline Myrcia tomentosa (Aubl.) DC. & & $\mathrm{x}$ & $\mathrm{Z}$ & S & I & $\mathrm{T}$ \\
\hline Myrcia venulosa DC. & & $\mathrm{X}$ & $\mathrm{Z}$ & S & $\mathrm{T}$ & $\mathrm{T}$ \\
\hline
\end{tabular}


Table 1. Continuation.

\begin{tabular}{|c|c|c|c|c|c|c|}
\hline Family/Species & Non invaded area & Invaded area & DS & GR & ST & SF \\
\hline \multicolumn{7}{|l|}{ PERACEAE } \\
\hline Pera glabrata (Schott) Poepp. ex Baill. & & $\mathrm{X}$ & $\mathrm{Z}$ & $\mathrm{M}$ & $\mathrm{T}$ & $\mathrm{T}$ \\
\hline \multicolumn{7}{|l|}{ PRIMULACEAE } \\
\hline Myrsine coriacea (Sw.) R.Br. ex Roem. \& Schult. & $\mathrm{X}$ & $\mathrm{X}$ & $\mathrm{Z}$ & M & I & $\mathrm{T}$ \\
\hline Myrsine umbellata Mart. & $\mathrm{X}$ & $\mathrm{X}$ & $\mathrm{Z}$ & M & $\mathrm{T}$ & $\mathrm{T}$ \\
\hline \multicolumn{7}{|l|}{ ROSACEAE } \\
\hline Prunus myrtifolia (L.) Urb. & $\mathrm{X}$ & $\mathrm{X}$ & Z & S & $\mathrm{T}$ & $\mathrm{T}$ \\
\hline \multicolumn{7}{|l|}{ RUTACEAE } \\
\hline Citrus $x$ limon (L.) Osbeck & $\mathrm{X}$ & & $\mathrm{Z}$ & & & \\
\hline Esenbeckia febrifuga (A. St.-Hil.) A.Juss. ex Mart. & $\mathrm{X}$ & $\mathrm{X}$ & $\mathrm{NZ}$ & $\mathrm{F}$ & I & \\
\hline Helietta apiculata Benth. & & $\mathrm{X}$ & $\mathrm{NZ}$ & M & $\mathrm{T}$ & \\
\hline Zanthoxylum rhoifolium Lam. & $\mathrm{X}$ & $\mathrm{x}$ & $\mathrm{Z}$ & M & $\mathrm{T}$ & $\mathrm{T}$ \\
\hline \multicolumn{7}{|l|}{ SALICACEAE } \\
\hline Casearia gossypiosperma Briq. & $\mathrm{X}$ & & $\mathrm{NZ}$ & M & $\mathrm{T}$ & $\mathrm{T}$ \\
\hline Casearia sylvestris $\mathrm{Sw}$. & $\mathrm{X}$ & $\mathrm{X}$ & $\mathrm{Z}$ & M & $\mathrm{T}$ & $\mathrm{S}$ \\
\hline \multicolumn{7}{|l|}{ SAPINDACEAE } \\
\hline Allophylus edulis (A.St.-Hil. et al.) Hieron. ex Niederl. & $\mathrm{X}$ & $\mathrm{X}$ & $\mathrm{Z}$ & S & $\mathrm{T}$ & \\
\hline Matayba elaeagnoides Radlk & $\mathrm{X}$ & & $\mathrm{Z}$ & $\mathrm{M}$ & $\mathrm{T}$ & $\mathrm{T}$ \\
\hline \multicolumn{7}{|l|}{ SAPOTACEAE } \\
\hline Pouteria ramiflora (Mart.) Radlk. & & $\mathrm{x}$ & $\mathrm{Z}$ & M & $\mathrm{T}$ & S \\
\hline \multicolumn{7}{|l|}{ SIPARUNACEAE } \\
\hline Siparuna guianensis Aubl. & & $\mathrm{x}$ & Z & M & $\mathrm{T}$ & S \\
\hline \multicolumn{7}{|l|}{ STYRACACEAE } \\
\hline Styrax camporum Pohl & $\mathrm{X}$ & & Z & S & I & $\mathrm{T}$ \\
\hline Styrax pohlii A. DC. & & $\mathrm{x}$ & $\mathrm{Z}$ & S & I & $\mathrm{T}$ \\
\hline \multicolumn{7}{|l|}{ SYMPLOCACEAE } \\
\hline Symplocos revoluta Casar. & & $\mathrm{x}$ & $\mathrm{Z}$ & & & \\
\hline \multicolumn{7}{|l|}{ VOCHYSIACEAE } \\
\hline Qualea cordata (Mart.) Spreng. & $\mathrm{X}$ & & $\mathrm{NZ}$ & S & I & $\mathrm{T}$ \\
\hline Qualea grandiflora Mart. & $\mathrm{X}$ & & $\mathrm{NZ}$ & S & I & $\mathrm{S}$ \\
\hline Vochysia tucanorum Mart. & $\mathrm{X}$ & $\mathrm{X}$ & $\mathrm{NZ}$ & S & I & $\mathrm{S}$ \\
\hline
\end{tabular}

Table 2: Values of the Jaccard similarity index between communities and between strata within the communities of cerradão invaded (I) and non-invaded (NI) by Pteridium arachnoideum at Assis Ecological Station, SP, Brazil.

\begin{tabular}{|c|c|c|c|c|c|}
\hline & NI_upper & NI_intermediate & NI_lower & I_upper & I_intermediate \\
\hline NI_upper & - & - & - & - & - \\
\hline NI_intermediate & 0.25 & - & - & - & - \\
\hline NI_lower & 0.49 & 0.25 & - & - & - \\
\hline I_upper & 0.37 & - & - & - & - \\
\hline I_intermediate & - & 0.57 & - & 0.51 & - \\
\hline I_lower & - & - & 0.59 & 0.13 & 0.27 \\
\hline
\end{tabular}




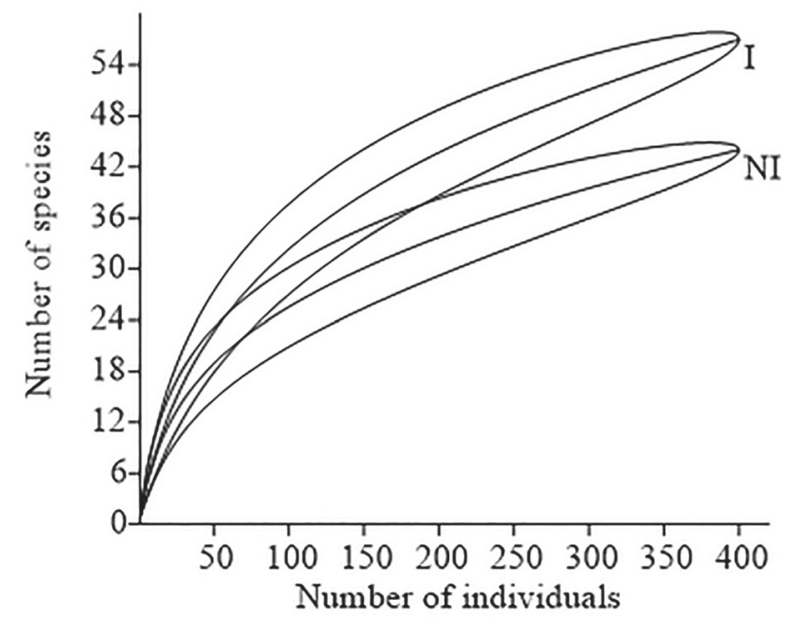

Figure 2. Rarefaction curves generated through the bootstrapping process for species recorded among 400 individuals sampled by the point-centered quarter method in areas of cerradão invaded (I) and non-invaded (NI) by Pteridium arachnoideum at Assis Ecological Station, SP, Brazil.

ant $\left(\chi^{2}=13.1292 ; d f=1 ; p<0.01\right.$; Fig. 3B $)$; had fast growth $\left(\chi^{2}=14.5195 ; d f=2 ; p<0.01 ;\right.$ Fig. 3C $)$; and were susceptible to frost $\left(\chi^{2}=15.1261 ; d f=1 ; p<0.01\right.$; Fig. 3D) in comparison with the non-invaded community (Tab. 1).

The basal area (Fig. 4) and absolute density of native species in all strata (Fig. 5) were higher in the non-invaded than in the invaded community (Tab. 3). In the upper stratum, density was 2.5 times $(\mathrm{t}=-9.3877 ; d f=28 ; p<0.01)$ and basal area was 1.6 times the values recorded in the invaded area $(\mathrm{t}=-4.1481 ; d f=2 ; p<0.01)$. In the intermediate layer, the density of the non-invaded vegetation was 4.5 times $\left(\chi^{2}\right.$ $=21.8862 ; d f=1 ; p<0.01)$ and basal area was five times the values recorded in the invaded vegetation $\left(\chi^{2}=17.5008\right.$; $d f=1 ; p<0.01)$. In the lower stratum, the non-invaded community had six times more individuals per area than the invaded community $\left(\chi^{2}=21.8422 ; d f=1 ; p<0.01\right)$. Tree canopy cover was $74.3 \% \pm 13.9 \%$ in the invaded community, compared with $99.6 \% \pm 0.7 \%$ without invasion (Fig. 6). Density in the lower stratum decreased as ground cover by $P$. arachnoideum necromass increased ( $\mathrm{rs}=-0.38$, $p<0.0026)$. However, no correlation between frond density and density in the lower stratum was observed.

Comparing the distribution of the individuals among size classes in the two communities (Fig. 7), the proportion of large trees (in height and DBH) was higher in the invaded community $\left(\chi^{2}=77.0935 ; d f=1 ; p<0.01\right)$ than in the non-invaded community $\left(\chi^{2}=52.871 ; d f=1 ; p<0.01\right)$.

\section{Discussion}

Bracken invasion affected the floristic composition and vegetation structure, and modified the tree community dynamics in the cerradão. However, we did not find lower species richness in the invaded area than in the adjacent non-invaded area.

The impact of invasion on the tree community structure was pronounced. Density and basal area of the woody spe-
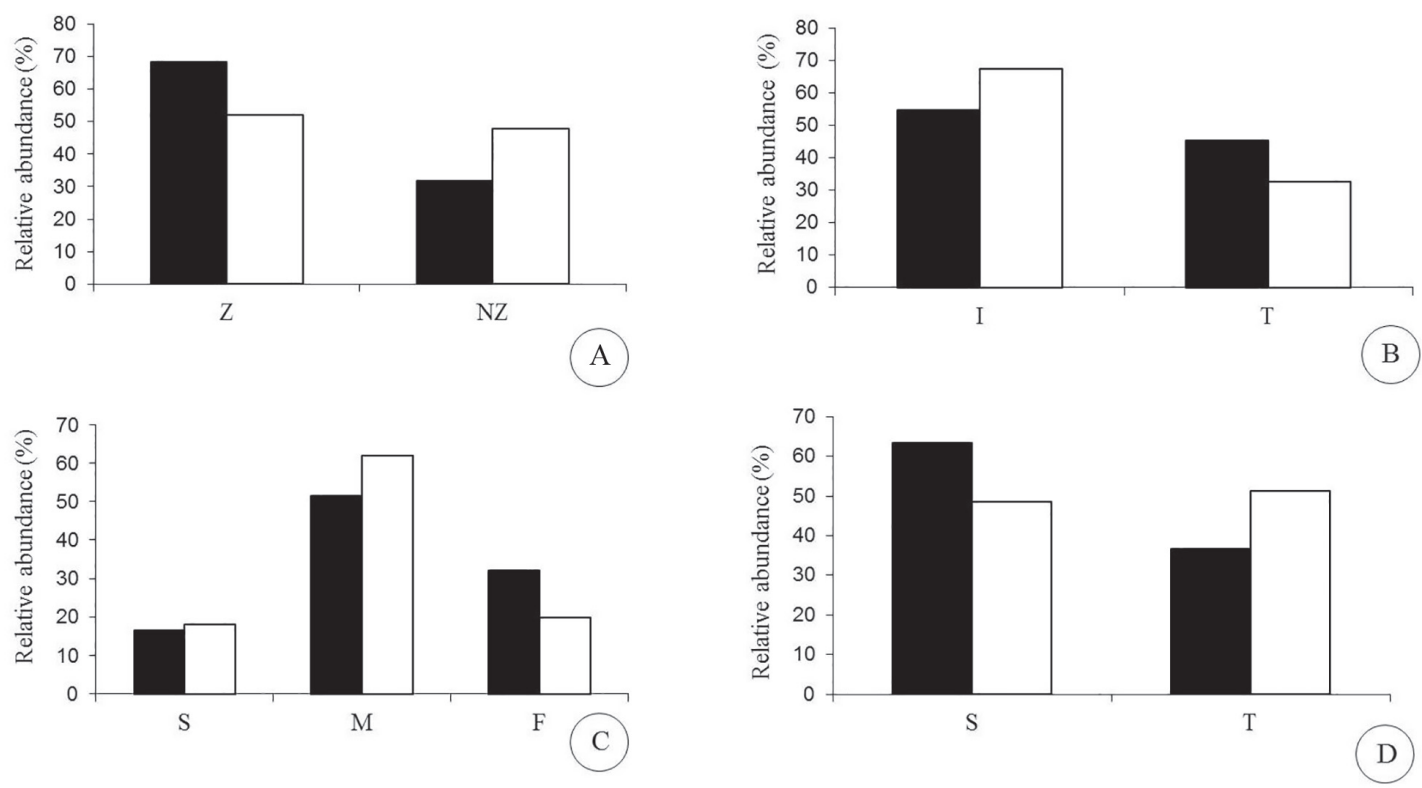

Invaded area Non-invaded area

Figure 3. Relative abundance of plant functional traits among individuals sampled in areas of cerradão invaded and non-invaded by Pteridium arachnoideum at Assis Ecological Station, SP, Brazil. A: seed dispersal syndrome (Z: zoochorous; NZ: non-zoochorous); B: shade tolerance (T: tolerant, I: intolerant); C: growth rhythm (F: fast, M: moderate, S: slow); D: susceptibility to frost (T: tolerant to frost, S: susceptible to frost) 


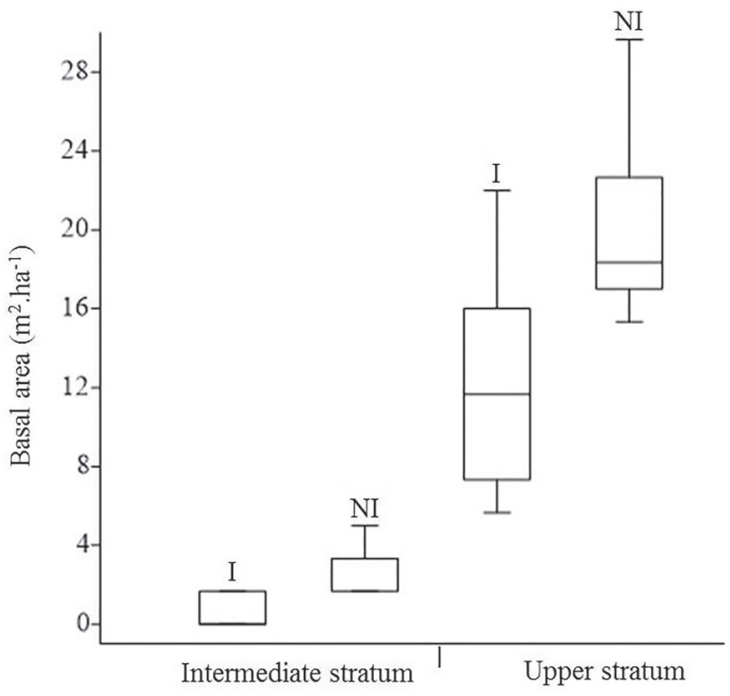

Figure 4. Box plot of basal area $\left(\mathrm{m}^{2} \mathrm{ha}^{-1}\right)$ in the intermediate and upper strata of the arboreal community of cerradão invaded (I) and non-invaded (NI) by Pteridium arachnoideum at Assis Ecological Station, SP, Brazil. The box is bounded by the first and third quartiles, the line inside the box is the median, and the whiskers extend to 1.5 times the interquartile range, giving a measure of dispersion in the data.

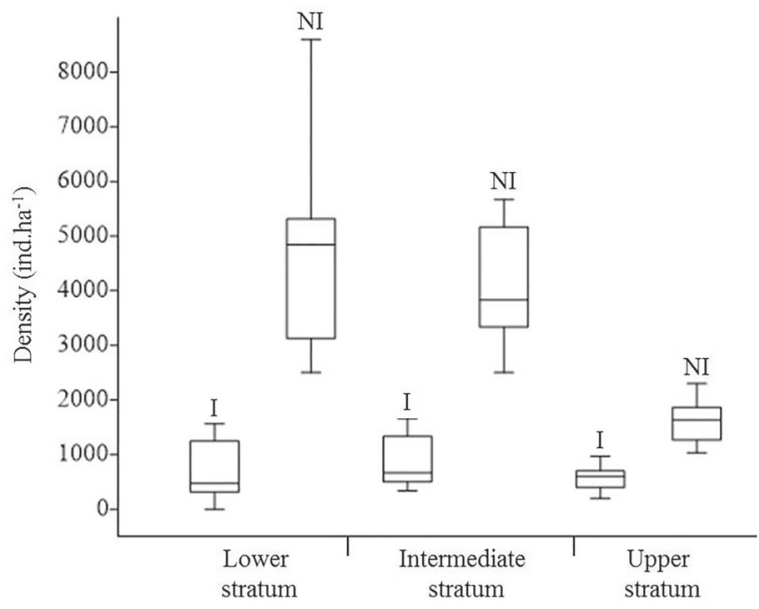

Figure 5: Box plot of density (individuals ha ${ }^{-1}$ ) of individuals in the lower, intermediate, and upper strata of the arboreal community of cerradão invaded (I) and non-invaded (NI) by Pteridium arachnoideum at Assis Ecological Station, SP, Brazil. The box is bounded by the first and third quartiles, the line inside the box is the median, and the whiskers extend to 1.5 times the interquartile range, giving a measure of dispersion in the data.

Table 3. Density and basal area for the lower, intermediate, and upper strata of the arboreal community of cerradão invaded and non-invaded by Pteridium arachnoideum at Assis Ecological Station, SP, Brazil. Different letters means significant difference at the $5 \%$ level.

\begin{tabular}{lcccc}
\hline Strata & \multicolumn{2}{c}{$\begin{array}{c}\text { Absolute density } \\
\left(\text { individuals ha }{ }^{-1}\right)\end{array}$} & \multicolumn{2}{c}{$\begin{array}{c}\text { Basal area } \\
\left(\mathrm{m}^{2} \mathrm{ha}^{-1}\right)\end{array}$} \\
\hline & Invaded & Non-invaded & Invaded & Non-invaded \\
Upper & $580 \pm 212^{\mathrm{a}}$ & $1578 \pm 353^{\mathrm{b}}$ & $12.80 \pm 5.40^{\mathrm{a}}$ & $20.40 \pm 4.52^{\mathrm{b}}$ \\
Intermediate & $867 \pm 442^{\mathrm{a}}$ & $4133 \pm 1049^{\mathrm{b}}$ & $0.55 \pm 0.81^{\mathrm{a}}$ & $2.66 \pm 1.05^{\mathrm{b}}$ \\
Lower & $708 \pm 511^{\mathrm{a}}$ & $4583 \pm 1642^{\mathrm{b}}$ & - & - \\
\hline
\end{tabular}

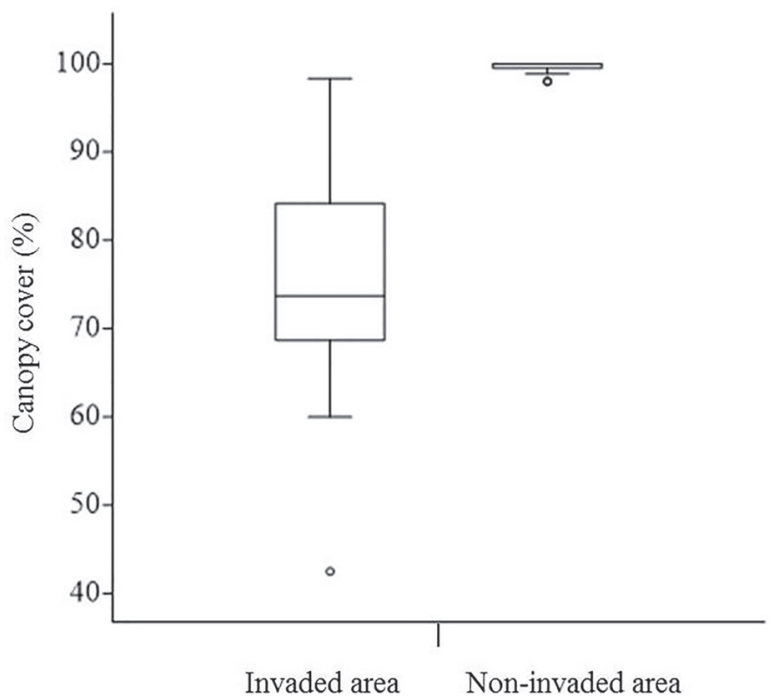

Figure 6: Box plot of canopy cover in areas of cerradão invaded and non-invaded by Pteridium arachnoideum at Assis Ecological Station, SP, Brazil. The box is bounded by the first and third quartiles, the line inside the box is the median, and the whiskers extend to 1.5 times the interquartile range, giving a measure of dispersion in the data. All data outside the whisker range are considered outliers and are represented by open circles.
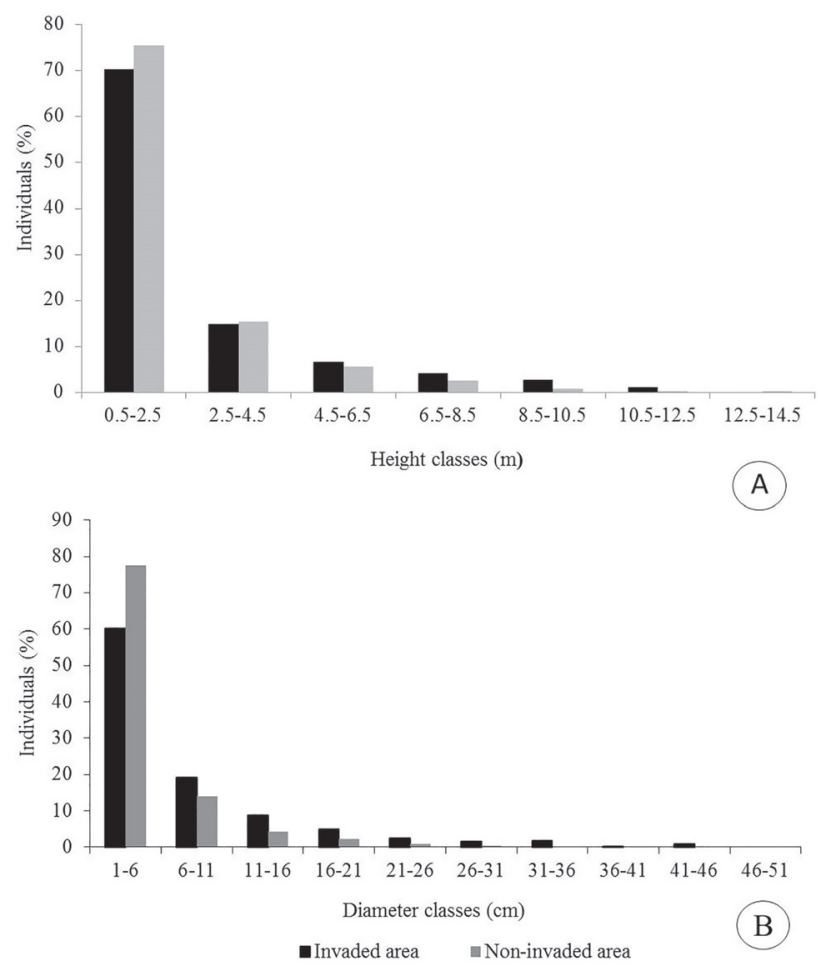

Figure 7: Histogram of size classes based on the percentage of individuals in the community according to tree height (A) and DBH (B) in areas of cerradão invaded and non-invaded by Pteridium arachnoideum at Assis Ecological Station, SP, Brazil. 
cies were lower and adult individuals achieved greater height and stem diameter in the invaded community than in the non-invaded community, presumably because competition was more intense in the latter.

Even though the invasion slowed down the regeneration processes of woody vegetation, the bracken did not prevent succession towards physiognomy and floristic composition of the cerradão, a Cerrado type where life forms other than trees are very rare. Invaded areas within EEcA encompassed 90.7 ha in 1994 but was reduced to 39.2 ha in 2006, a reduction of more than $40 \%$ in 12 years (Pinheiro \& Durigan 2009).

The upper stratum of the forest differed between the two communities with respect to species composition and functional traits. The species dominating the overstory in the invaded area were shade tolerant and fast growing, attributes that allowed them to overcome the physical barrier imposed by bracken in the beginning of succession. In turn, the lower stratum was functionally and floristically similar between communities, indicating that the differences that occurred during the colonization processes tended to disappear over time because of the facilitation provided by the first colonizers.

These results contrast with those of previous studies that found a decrease in richness and diversity after plant invasion by other species (Pinus elliottii var. elliottii, studied by Abreu \& Durigan 2011 and Schizolobium parahyba, analyzed by Abreu et al. 2014) or by bracken in other situations (Ghorbani et al. 2006; Mack et al. 2000; Portela et al. 2009). In the study region, the very severe frosts that were able to damage the native Cerrado vegetation (Brando \& Durigan 2004) may also have reduced the Pteridium arachnoideum population (Watt 1954). Consistent with the Pteridium cyclic model proposed by Watt (1945), this event could have allowed for re-colonization of the areas by native woody species, despite the bracken invasion that had been occurring for over 50 years. The cyclic model suggests that bracken has periods of density increase and decrease through time. New individuals develop over the dense litter layer formed by the bracken fronds and become more susceptible to droughts or frosts. In turn, the new fronds are smaller, thereby decreasing the litter layer. The mortality rate then increases, opening gaps in the bracken layer and allowing for the establishment of woody species that were unable to occupy the areas densely covered by bracken.

In areas invaded by bracken in Ecuador, Hartig \& Beck (2003) found a pattern of vegetation similar to that observed in this study, with shrubs, mainly Asteraceae and Melastomataceae, permeating the Pteridium patches. However, due to the low resilience of native forest in that region caused by the frequent use of fire for agriculture, the vegetation structure remains in an alternative stable state and cannot regenerate by itself, thus, it requires intervention.

In the cerradão, there were apparently no active ecological filters preventing or reducing the arrival of propagules of tree species in the area with bracken, and species rich- ness was higher than in the adjacent non-invaded area. Moreover, the species found in the invaded area were mostly animal dispersed, indicating that fauna visit the area, which increases the chance of new propagules arriving from the vicinity, thereby potentially increasing richness and species diversity. If there were active filters in the past, their restrictions may have been related to seedling establishment for the community as a whole, resulting in a low density of colonizing trees that acquired large sizes and broad canopies and created a mosaic of tree islands immersed in the bracken field. This environmental mosaic may be more suitable for the establishment of a larger number of species and functional groups compared with the non-invaded area, which presents a more homogeneous and consistent shady environment (Abreu et al. 2011).

Management decisions should ideally be based on an understanding of the ecological processes involved in the invasion and on quantifying the losses resulting from it (Durigan et al. 2013). In the studied ecosystem, bracken populations do not appear to be spreading or proliferating, and native species richness has not decreased over time in the invaded areas. Management intervention to control or eradicate bracken in the system studied here may not be urgent or even necessary. However, in other ecosystems or under different conditions, the course of succession may be different. The lack of effective sources of propagules may lead to the stagnation of the ecosystem after invasion by bracken, requiring management intervention to facilitate the arrival of species (planting). Moreover, a natural reversal of the invasion may not occur if the target vegetation is susceptible to fires, considering that Pteridium increases in density in post-fire environments (Roos et al. 2010; Silva \& Matos 2006). Bracken may also have a more lasting effect on non-forest vegetation, given that shading of bracken by trees appears to be the major mechanism by which the biotic filter imposed by bracken can be overcome. Management decisions should therefore be made on a case-by-case basis after a diagnosis of the local site conditions. The results from this study clarify several of the processes involved in the invasion of Cerrado areas by this species of bracken, which could inform management decisions in similar circumstances.

\section{Acknowledgements}

We are grateful to Antônio Carlos Galvão de Melo for his contribution in data collection; Rodolfo C. R. Abreu, J. Stephen Brewer, and two anonymous reviewers for their relevant comments on previous versions of the manuscript; Eduardo S. Pinheiro for preparing Figure 1; Forestry Institute of São Paulo for the logistical support to the research; Fundação de Amparo à Pesquisa do Estado de São Paulo - FAPESP for the scholarship grant to N.G.; and Conselho Nacional de Desenvolvimento Científico e Tecnológico$\mathrm{CNPq}$ for the research productivity grant to G.D. 


\section{References}

Abreu RCR, Durigan G. 2011. Changes in the plant community of a Brazilian grassland savannah after 22 years of invasion by Pinus elliottii Engelm. Plant Ecology \& Diversity 4: 269-278.

Abreu RCR, Assis GB, Frison S, Aguirre A, Durigan G. 2011. Can native vegetation recover after slash pine cultivation in the Brazilian Savanna? Forest Ecology and Management 262: 1452-1459.

Abreu RCR, Santos FFM, Durigan G. 2014. Changes in plant community of Seasonally Semideciduous Forest after invasion by Schizolobium parahyba at southeastern Brazil. Acta Oecologica 54: 57-64.

Bognola IA, Joaquim AC, Prado H, Menk JRF, Lepsch IF. 1996. Levantamento pedológico semidetalhado da Folha de Assis. Escala 1:100.000. São Paulo, Secretaria da Agricultura.

Brando PM, Durigan G. 2004. Changes in Cerrado vegetation after disturbance by frost (São Paulo State, Brazil). Plant Ecology 175: 205-215.

Canfield RH. 1941. Application of the line interception method in sampling range vegetation. Journal of Forestry 39: 388-394.

CEPAGRI - Centro de Pesquisas Meteorológicas e Climáticas Aplicadas a Agricultura. 2014. Clima dos Municípios Paulistas. www.cpa.unicamp. br/outras-informacoes/clima muni_047.html>. 20 Oct. 2014.

Cronk QCB, Fuller JL. 1995. Plant Invaders: The threat to natural ecosystems. London, Chapman \& Hall.

Durigan G, Siqueira MF, Franco GADC, Contieri WA. 2004. A flora arbustivo-arbórea do Médio-Paranapanema: bases para a restauração dos ecossistemas naturais. In: Vilas Boas O, Durigan G. (eds). Pesquisas em conservação e recuperação ambiental no Oeste Paulista: resultados da cooperação Brasil/Japão. São Paulo, Páginas \& Letras. p. 199-239.

Durigan G, Ivanauskas NM, Zakia MJB, Abreu RCR. 2013. Control of Invasive Plants: Ecological and Socioeconomic Criteria for the Decision Making Process. Natureza \& Conservação 11: 23-30.

Fenwick GR. 1989. Bracken (Pteridium aquilinum)- toxic effects and toxic constituents. Journal of the Science of Food and Agriculture 46: 147-173.

Furlan FH, Costa FL, Torres SCS, et al. 2014. Perfil de propriedades rurais com pastos invadidos por Pteridium arachnoideum na região norte de Mato Grosso e prevalência de hematúria enzoótica bovina. Pesquisa Veterinária Brasileira 34: 753-759.

Ghorbani J. Le Duc MG, McAllister HA, Pakeman RJ, Marrs RH. 2006. Effects of the litter layer of Pteridium aquilinum on seed banks under experimental restoration. Applied Vegetation Science 9: 127-136.

Gliessman SR, Müller CH. 1978. The allelopathic mechanisms of dominance in bracken in southern California. Journal of Chemical Ecology 4: 337-362.

Gorenstein MR, Batista JBF, Durigan G. 2007. Influência do padrão espacial sobre a estimativa de densidade arbórea do método de quadrantes: um estudo por meio de simulação de Monte Carlo. Acta Botanica Brasilica 21: 957-965.

Hammer Ø, Harper DAT, Ryan PD. 2001. PAST: Paleontological statistics software package for education and data analysis. Palaeontologia Electronica 4: 99p.

Hartig K, Beck E. 2003.The bracken (Pteridium arachnoideum (Kaulf.) Maxon) dilemma in the andes of southern Ecuador. Ecotropica 9:3-13.

Hojo-Souza NS, Carneiro CM, Santos RC. 2010. Pteridium aquilinum: o que sabemos e o que ainda falta saber. Bioscience Journal 26: 798-808.

Mack RN, Simberloff D, Lonsdale WM, Evans H, Clout M, Bazzaz F A. 2000. Biotic invasions: causes, epidemiology, global consequences, and control. Ecological Applications 10: 689-710.

Magurran AE. 1988. Ecological Diversity and its Measurement. Princeton, Princeton University Press.

Marrs RH, Le Duc MG, Mitchell RJ, Goddard D, Paterson S, Pakerman RJ. 2000. The Ecology of Bracken: Its role in succession and implications for control. Annals of Botany 85 (Supplement B): 3-15.
Marrs RH, Pakeman RJ, Le Duc MG, Paterson S. 1997. Bracken invasion in Scotland. Botanical Journal of Scotland 49: 347-356.

Marrs RH, Watt AS. 2006. Biological flora of the British Isles: Pteridium aquilinum (L.) Kuhn. Journal of Ecology 94: 1272-1321.

Matos DMS, Belinato TA. 2010. Interference of Pteridium arachnoideum (Kaulf.) Maxon. (Dennstaedtiaceae) on the establishment of rainforest trees. Brazilian Journal of Biology 70: 311-316.

Matos DMS, Pivello VR. 2009. O impacto das plantas invasoras nos recursos naturais de ambientes terrestres: alguns casos brasileiros. Ciência e Cultura 61: 27-30.

McGeoch MA, Butchart SHM, Spear D, et al. 2010. Global indicators of biological invasion: species numbers, biodiversity impact and policy responses. Diversity and Distributions 16: 95-108.

McKinney ML, Lockwood JL, 1999. Biotic homogenization: a few winners replacing many losers in the next mass extinction. Trends in Ecology and Evolution 14: 450-453.

Müller-Dombois D, Ellenberg H. 1974. Aims and methods of vegetation ecology. New York, Willey and Sons.

Norton DA. 2009. Species invasions and the limits to restoration: learning from the New Zealand Experience. Science 325: 569-570.

Pijl LVD. 1982. Principles of dispersal in higher plants. Berlin, Springer.

Pinheiro ES, Durigan G. 2009. Dinâmica espaço-temporal (1962-2006) das fitofisionomias em unidade de conservação do Cerrado no sudeste do Brasil. Revista Brasileira de Botânica 32: 441-454.

Pinheiro ES, Durigan G. 2012. Diferenças florísticas e estruturais entre fitofisionomias do Cerrado em Assis, SP, Brasil. Revista Árvore 36: 181-193.

Portela RCQ, Matos DMS, Siqueira LP, Braz MIG, Silva-Lima L, Marrs RH. 2009. Variation in aboveground biomass and necromass of two invasive species in the Atlantic rainforest, southeast Brazil. Acta Botanica Brasilica 23: 571-577.

R Development Core Team. 2009 R: A language and environment for statistical computing R Foundation for Statistical Computing Vienna, Austria.

Raizada P, Raghubanshi AS, Singh JS. 2008. Impact of invasive alien plant species on soil processes: a review. Proceedings of the National Academy of Sciences. India Section B, Biological Sciences 78: 288-298.

Roos K, Rollenbeck R, Peters T, Bendix J, Beck E. 2010. Growth of Tropical Bracken (Pteridium arachnoideum): Response to Weather Variations and Burning. Invasive Plant Science and Management 3: 402-411.

Salgado RS. 2012. Identificação de unidade de habitat (UH) para Pteridium aquilinum, em áreas selecionadas da área de proteção ambiental (APA) Gama e Cabeça de Veado, DF. Msc Thesis, Universidade Católica de Brasília, Brazil.

Silva USR, Matos DMS. 2006. The invasion of Pteridium aquilinum and the impoverishment of the seed bank in fire prone areas of Brazilian Atlantic Forest. Biodiversity and Conservation 15: 3035-3043.

Simberloff D, Rejmánek M. (eds). 2011. Encyclopedia of Biological Invasions. Berkeley, University of California Press.

Tokarnia CH, Döbereiner J, Peixoto PV. 2000. Plantas Tóxicas do Brasil. Rio de Janeiro, Helianthus.

Valéry L, Fritz H, Lefeuvre JC, Simberloff D. 2008. In search of a real definition of the biological invasion phenomenon itself. Biological Invasions 10: 1345-1351

Watt AS. 1945. Contributions to the ecology of bracken (Pteridium aquilinum) III. Frond types and the make-up of the population. New Phytologist 44: 156-178.

Watt AS. 1954. Contributions to the ecology of bracken (Pteridium aquilinum) VI. Frost and the advance and retreat of bracken. New Phytologist 53: 117-130.

Williamson M. 1996. Biological Invasions. London, Chapman \& Hall. 